\title{
THE ASSESSMENT AND REPAIR OF THE PRECAST RC STRUCTURE EXPOSED TO FIRE
}

\author{
Vlastimir Radonjanin \\ Faculty of Technical Sciences, University of Novi Sad, Novi Sad, Serbia \\ Mirjana Malešev \\ Faculty of Technical Sciences, University of Novi Sad, Novi Sad, Serbia \\ Ivan Lukić \\ Faculty of Technical Sciences, University of Novi Sad, Novi Sad, Serbia \\ Slobodan Šupić \\ Faculty of Technical Sciences, University of Novi Sad, Novi Sad, Serbia \\ Suzana Vukoslavčević \\ Faculty of Technical Sciences, University of Novi Sad, Novi Sad, Serbia
}

This paper presents the assessment and repair of precast $R C$ structure exposed to fire in Novi Sad. Detailed visual inspection, which includes described and classified damages and defects of RC columns and beams, is presented in the paper. Control design of the built-in concrete and reinforcement, as well as geodetic survey and conclusion on the state of the structure, are carried out. Two possible repair solutions were analysed.

Key words: RC structure, Fire, Visual inspection, Control design, Repair

\section{INTRODUCTION}

On May $5^{\text {th }}$ 2013. there was a fire in production hall-building "Uradi sam" in Novi Sad. Major interior parts with installations, roof coverings and facade's cladding, as well as complete roof-bearing structure have been destroyed during the fire. RC columns and RC facade beams have suffered serious damages. Object's appearances before and after fire and clearing the ground off, are presented in Figures 1 and 2.

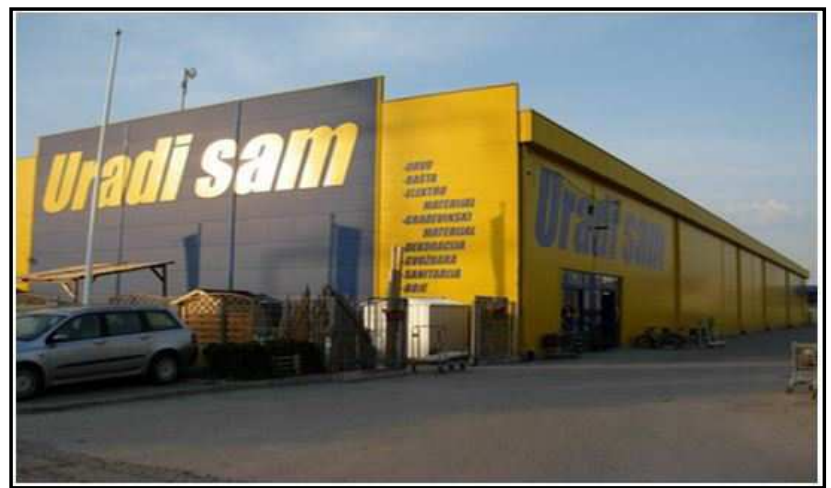

Figure 1: Object's appearance before fire

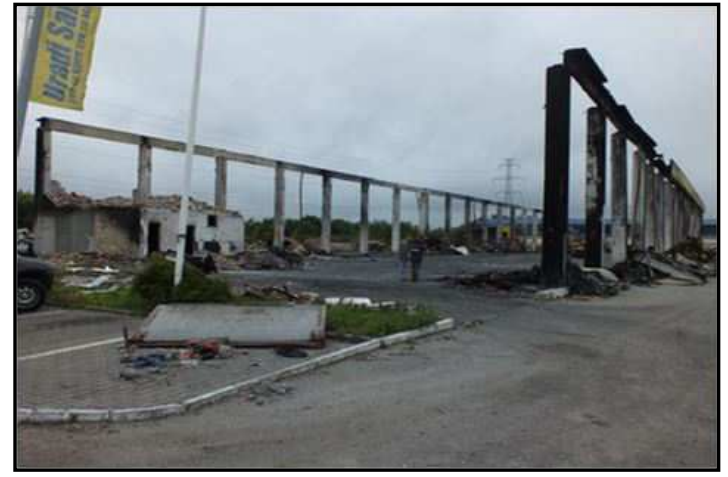

Figure 2: Object's appearance after fire and clearing the ground off

\section{VISUAL INSPECTION AND ANALYSE OF DETECTED DEFECTS AND DAMAGES}

Detailed visual inspection of all RC columns and beams, as well as measuring of dimensions, in order to compare them with the originals, have been made.

During the detailed visual inspection of the elements, following defects and damages were registered:

- insufficient protective concrete layer,

- rough concrete surfaces, 
- spalled, fallen off or burnt concrete protection layer,

- changed surface concrete's colour,

- crumbly and burnt concrete protective layer with aggregate grains of changed colour,

- crumbly longitudinal column edges,

- net-like fissures on the surface of the elements,

- horizontal cracks along stirrups,

- horizontal cracks due to flexion of columns,

- vertical cracks and gapes along column edges (along main reinforcement),

- breaking, spalling and falling of concrete along the edge of columns,

- the impaired adhesion between concrete and reinforcement,

- exposed reinforcement,

- local mechanical damages of concrete on places where interior elements were fixed.

Characteristic defects and damages after fire are presented in figures 3 to 7 .

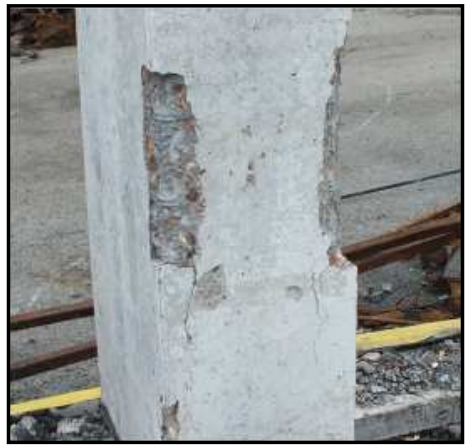

Figure 3:Cracking, separation and peeling of concrete along the column edges (up to the main longitudinal reinforcement), pronounced change in aggregate colour, net-like fissures

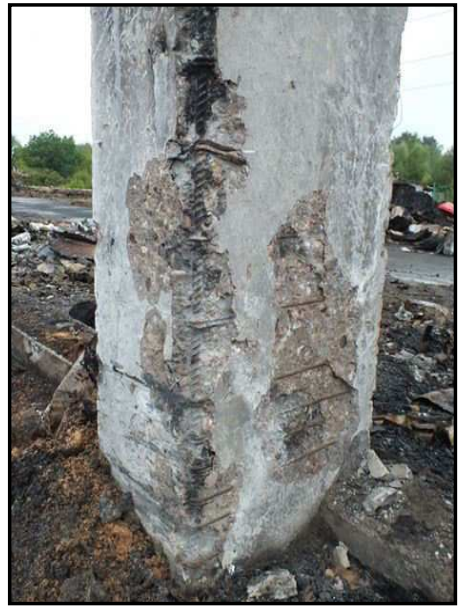

Figure 4: Peeling of crumbly protective layer of concrete, visible reinforcement

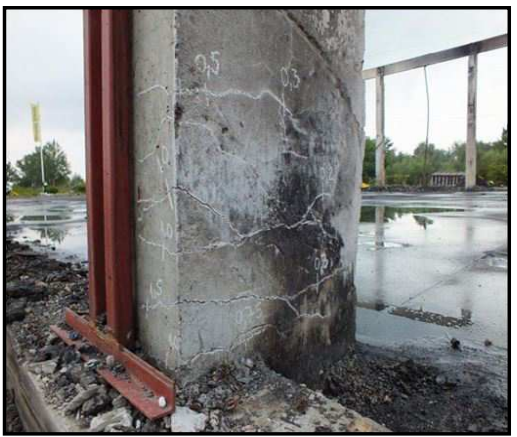

Figure 5: Horizontal cracks due to flexion of column (during the collapse of roof structure)

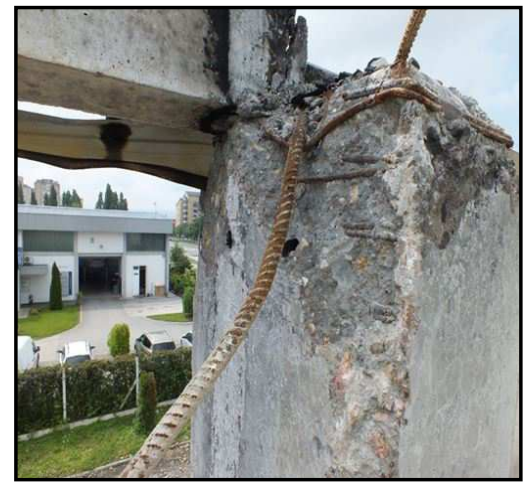

Figure 6: Crumbling of concrete in the supporting zone, peeling of surface and protective concrete layers, deformed stirrups and anchors, change in aggregate colour

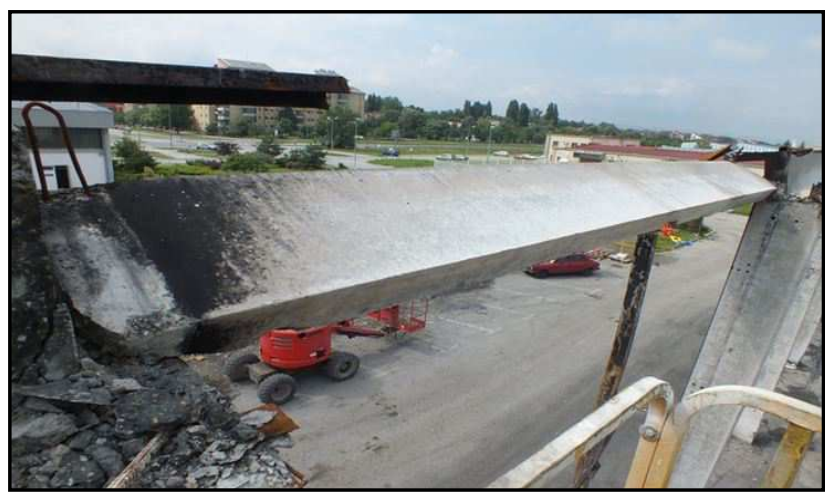

Figure 7: Beam rotation (tends to decline)

\section{SUBSEQUENT QUALITY CONTROL OF BUILT-IN CONCRETE}

In order to determine actual compressive strength of concrete after fire, concrete samples (concrete cylinders) are taken from basic structure elements: columns, beams and floor slab. Cylinders are used to evaluate compressive strength of concrete, as well as to determine the depth of burnt concrete layer and detect internal cracks. Compressive strength of concrete cylinders, recalculated to compressive strengths of concrete cubes with $20 \mathrm{~cm}$ edge, are presented in Table 1. 
After detailed analyze and evaluation of compressive strength of concrete after fire, it was concluded that compact concrete core exists in all of the RC elements, it has satisfactory mechanical properties and designed compressive strength class C35/45.

\section{SUBSEQUENT QUALITY CONTROL OF BUILT-IN REINFORCEMENT}

Samples of ribbed reinforcement are taken to determine the quality of reinforcement after fire. Reinforcement bars were taken from RC beam - binding rafter, which remained standing after clearing the demolished roof structure. Tensile strength, yield strength and unit breaking elongation were determined during the laboratory examination. Results are presented in Table 2.

\section{GEODETIC SURVEY OF THE VERTICALITY OF THE COLUMNS}

Geodetic survey, which included eleven spots on every column, was realised. Schematic display of movement of the top of the column in relation to vertical axis, is presented in the Figure 8.

Table 1: Basic statistical parameters for assessment of compressive strength of concrete

\begin{tabular}{|l|c|c|c|}
\hline \multicolumn{1}{|c|}{ Element } & Number of cylinders & $\begin{array}{c}\text { Mean value of com- } \\
\text { pressive strength } \\
(\mathrm{MPa})\end{array}$ & $\begin{array}{c}\text { Min. value of compres- } \\
\text { sive strength (MPa) }\end{array}$ \\
\hline RC columns, axis A & 5 & 59.2 & 52.7 \\
\hline RC columns, axis B & 5 & 56.5 & 47.4 \\
\hline RC beams, axis A & 3 & 44.4 & 39.4 \\
\hline RC beams, axis B & 3 & 44.7 & 37.3 \\
\hline RC floor slab & 3 & 58.7 & 55.7 \\
\hline
\end{tabular}

Table 2: Mechanical characteristics of examined reinforcement samples

\begin{tabular}{|c|c||c|c|c|}
\hline Sample mark & $\begin{array}{c}\text { Sample dimen- } \\
\text { sions } \\
(\mathrm{mm})\end{array}$ & $\begin{array}{c}\text { Yield strength } \\
\mathrm{Rp}(\mathrm{MPa})\end{array}$ & $\begin{array}{c}\text { Tensile strength } \\
\mathrm{Rm}(\mathrm{MPa})\end{array}$ & $\begin{array}{c}\text { Unit breaking } \\
\text { elongation A (\%) }\end{array}$ \\
\hline $\mathrm{D} 1$ & $\varnothing 18$ & 463 & 552 & 13,3 \\
\hline $\mathrm{D} 2$ & $\varnothing 18$ & 440 & 525 & 14 \\
\hline $\mathrm{D} 3$ & $\varnothing 18$ & 447 & 526 & - \\
\hline $\mathrm{G} 1$ & $\varnothing 18$ & 482 & 546 & 14,4 \\
\hline $\mathrm{G} 2$ & $\varnothing 18$ & 505 & 577 & - \\
\hline G3 & $\varnothing 18$ & 482 & 550 & 10 \\
\hline \hline Min. (SRPS C.K6.020) & 400 & 500 & 10 \\
\hline \hline
\end{tabular}

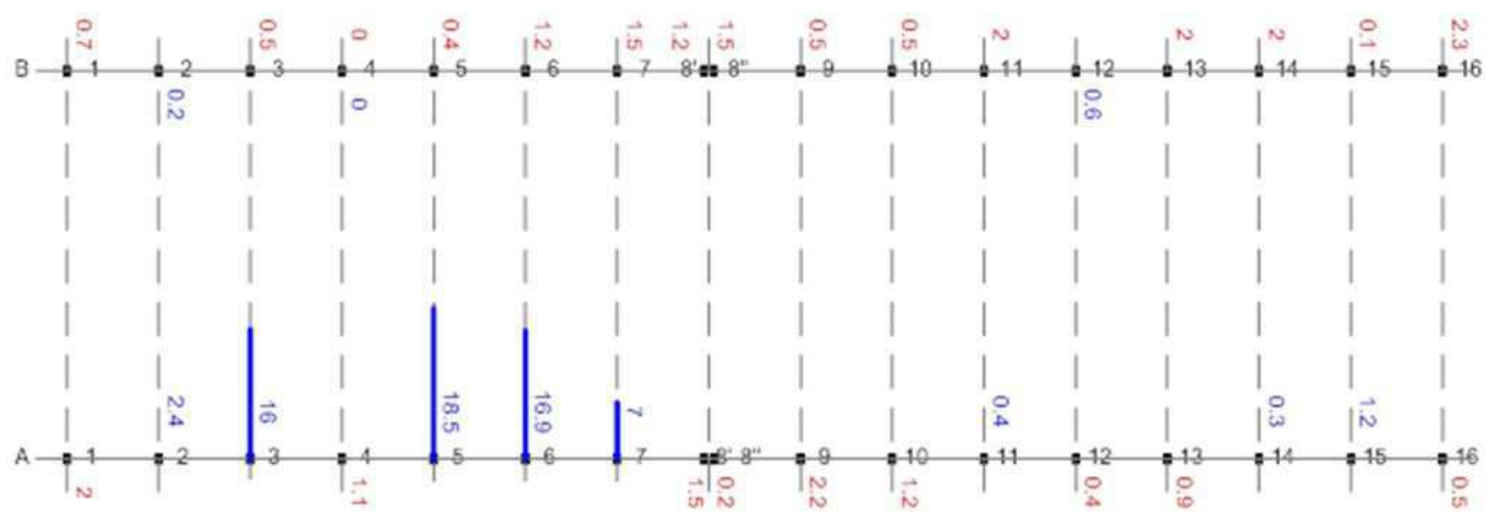

Figure 8: Schematic display of movement of the top of the column in relation to vertical axis 
Columns A3, A5, A6 and A7 are evidently inclined towards the interior of the hall. Deviations of top parts of these columns in relation to fixed part of the column, i.e. in relation to the axis of non-deformed column, are great and are between 71$185 \mathrm{~mm}$. Most of the columns were not deformed, nor was there excess of tension due to bending, because the main roof carrier fell from their supports relatively fast. However, on columns A3, A5, A6 and A7 connection between anchors on the top of the column and main roof carriers broke only after columns started to bend.

\section{CONCLUSION ON THE STATE OF THE STRUCTURE}

During the fire, which occurred in the building hall "Uradi Sam" in Novi Sad, major interior parts with installations, roof coverings and facade's cladding, as well as complete roof-bearing structure have been destroyed during the fire. Remaining elements of the bearing structure RC columns and RC facade beams suffered serious damages, while the floor slab had just surface damages. Mechanical properties of the built-in materials: concrete and reinforcement haven't been reduced after fire. Degree and nature of damage of the elements caused by fire had such an influence on the structure, that structure load bearing capacity is reduced at all the RC columns and beams, while stability is compromised at some of them.

\section{REPAIR SOLUTIONS}

Two possible repair solutions were analyzed. Variant I includes repair of RC columns, while variant II includes removal of existing and concreting the new RC columns. Both methods predict removal of existing facade RC beams, which suffered serious damages during the fire.

\section{Variant 'I"}

Repair solution includes:

- removing crumbly and burnt concrete all over the columns;

- complete removal of protective concrete layer in upper part of the columns (internal cracks and segregation have been registered there);

- cleansing the uncovered reinforcement from traces of corrosion;

- local reprofiling of crumbly and detached longitudinal edges of the columns (until the designed dimensions are accomplished) with micro-reinforced repair mortar;

- strengthening the columns with additional stirrups;

- local repair of crumbly, cracked and burnt parts of columns and concreting new protective layer in upper parts of the columns.

Manual or machine chiselling of cracked, loose and burnt concrete is needed at all columns. Chiselling is continued until all of the crumbly parts are removed. Plan of making the slits, where new stirrups are confined, as well as new cross section of rapaired column, are presented in Figure 9.

\section{Variant 'II"'}

Second variant includes: removal of the upper parts above $2 \mathrm{~m}$ of every column; chiselling of concrete and uncovering the reinforcement above $1.5 \mathrm{~m}$ of every column; cleansing the uncovered reinforcement from traces of corrosion, placing the new reinforcement and bonding it with existing one; planking and concreting new columns. Diamond wire can be used to cut and remove upper parts of the columns. In order to provide enough space to bond existing and new reinforcement, chiselling of concrete is scheduled above $1.5 \mathrm{~m}$ of every column up to $2 \mathrm{~m}$, where columns have been previously cut with the wire. Further actions of this solution include: manual or machine chiselling of cracked, crumbly and burnt concrete below $1.5 \mathrm{~m}$ of every column; cleansing the uncovered reinforcement from traces of corrosion; cleaning and washing chiselled concrete; placing the new longitudinal reinforcement and bonding it with existing one using electric welding; strengthening the longitudinal reinforcement with new stirrups $\phi 8 / 15$ in the middle and $\phi 8 / 7.5$ in the upper part of every column, planking and concreting new columns (figure 10).

\section{CONCLUSION}

If we want to compare these two solutions from the economic point of view, detailed techno-economic analyse is needed. However, taking scope of work, disposable materials and experts into account, second method has some advantages, especially considering this: removing the columns can be performed in a short period of time, 
because they stand free and unbonded with other elements; repair techniques and strengthening of damaged $\mathrm{RC}$ elements require special materials, equipment and methods, which take considerably more time; a lot of companies are able to perform classical construction works, while repair methods and strengthening of elements belong to the group of specialized works, which only some of the companies are capable of. On the other hand, first variant has the advantages in terms of consumption of concrete and reinforcement. Table 3 presents selection of variants with various aspects.

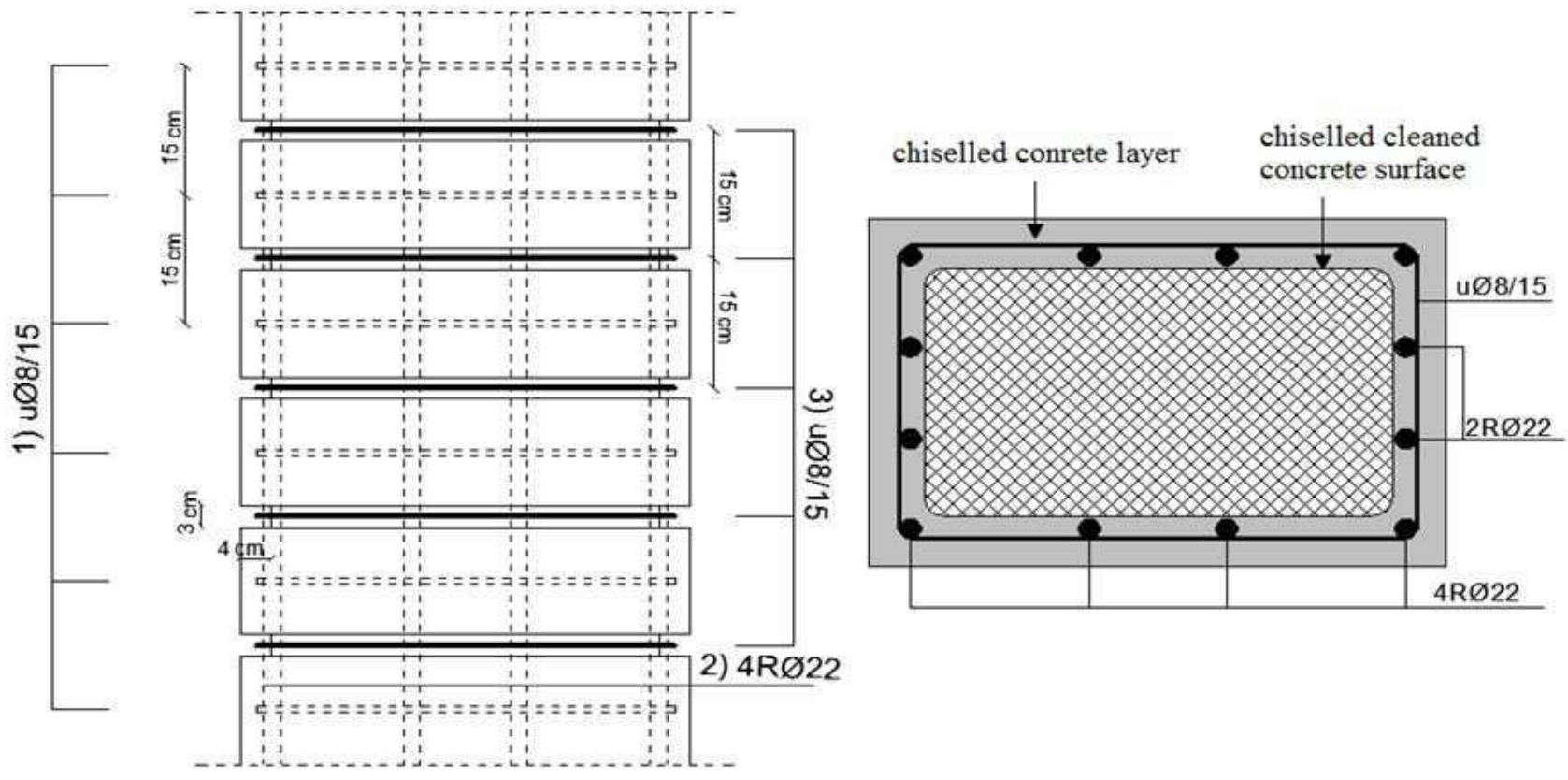

Figure 9: Details of the repair of RC columns

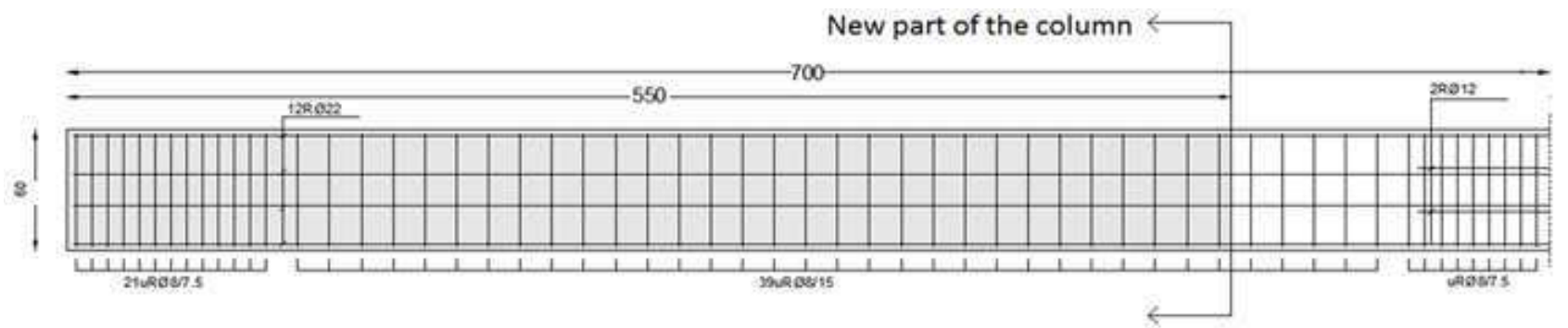

Figure 10: Concreting the new column

Table 3: Variant selection with various aspects

\begin{tabular}{|l|c|}
\hline & Variant selection \\
\hline Scope of work & Variant II \\
\hline Duration of works & Variant II \\
\hline Consumption of concrete & Variant I \\
\hline Consumption of reinforcement & Variant I \\
\hline Disposable materials & Variant II \\
\hline Disposable companies & Variant II \\
\hline
\end{tabular}




\section{REFERENCES}

1) Concrete Repair Manual, Second Edition, Volume 1 and 2, ACl, pp.2093, 2003.

2) Elaborat o kvalitetu materijala ugrađenog $u$ konstrukciju proizvodne hale "TEHNOBIRO" (građevinski dnevnik i izveštaji o ispitivanju ugrađenih materijala)

3) Eropean Standards for Repair and Protection of Concrete, Huwel Davies Consultancy, 2001.

4) Glavni arhitektonski projekat - Preduzeće za proizvodnju, izgradnju, rekonstrukciju, projektovanje i trgovinu na veliko i malo, P.O. "TIPING" doo - Beograd
5) Glavni projekat konstrukcije - Preduzeće za projektovanje i konsalting "BMSK" doo Beograd

6) Monitoring and Assessment of structures, G.S.T. Armer, New York, Spon Press, pp. 167, 2001.

7) Structural Design for Fire Safety, Andrew H. Buchanan, Wiley, pp.421, 2002.

8) V. Radonjanin, M. Malešev: Materijal sa predavanja iz predmeta "Trajnost i procjena stanja betonskih konstrukcija" i "Sanacija betonskih konstrukcija

Paper sent to revision: 26.05.2014.

Paper ready for publication: 01.02.2016. 
doi:10.5937/jaes14-6150

Broj rada: 14(2016)1, 346

\section{PROCENA STANJA I SANACIJA MONTAŽNE AB KONSTRUKCIJE NAKON POŽARA}

Vlastimir Radonjanin, Univerzitet u Novom Sadu, Fakultet Tehničkih nauka, Novi Sad Mirjana Malešev, Univerzitet u Novom Sadu, Fakultet Tehničkih nauka, Novi Sad Ivan Lukić, Univerzitet u Novom Sadu, Fakultet Tehničkih nauka, Novi Sad Slobodan Šupić, Univerzitet u Novom Sadu, Fakultet Tehničkih nauka, Novi Sad Suzana Vukoslavčević, Univerzitet u Novom Sadu, Fakultet Tehničkih nauka, Novi Sad

$U$ radu je data procena stanja i sanacija montažne $A B$ konstrukcije u Novom Sadu nakon požara. Rad sadrži rezultate detaljnog vizuelnog pregleda, gde su prikazana i klasifikovana registrovana oštećenja i defekti za AB stubove i grede, kontrolu kvaliteta ugrađenih materijala, geodetsko snimanje vertikalnosti stubova i zaključak o stanju konstukcije. Data su i obrazložena dva od nekoliko mogućih sanaciona rešenja.

Ključne reči: AB konstrukcija, Požar, Vizuelni pregled, Kontrolni proračun, Sanacija 